$\mathbb{T}$ periodica polytechnica

\author{
Architecture \\ 40/2 (2009) 77,86 \\ doi: 10.3311/pp.ar.2009-2.04 \\ web: http://www.pp.bme.hu/ar \\ (c) Periodica Polytechnica 2009
}

RESEARCH ARTICLE

\section{Late baroque greek-cross plan type Lutheran churches in Hungary}

János Krähling / Gergely Domonkos Nagy

Received 2010-02-18

\begin{abstract}
The paper analyses a specific building type, the Baroque church architecture of historic Hungary, the Greek-cross ground-plan evangelic churches. This church type has different prototypes: the Huguenot and Scandinavian Protestant churches in Europe, the model plans of architectural treatises - first of all the treatises of Leonhard Christoph Sturm - and the Lutheran wooden churches of Silesia. The symbolic content of the cruciform plan was also popular among the Lutheran congregations, which is explainable with theological reasons as well as with the good visual and acoustic conditions, furthermore with the construction benefits from its application. The Slovak Lutheran congregations played a determining role in the domestication and the dissemination of the layout type. The late Baroque central Greek-cross plan is an important antecedent for the renewal of the late $19^{\text {th }}$ century Protestant church architecture.
\end{abstract}

\section{Keywords}

Baroque architecture . Protestant church architecture . Lutheran churches - evangelic churches - Greek-cross plan . hungarian Architecture - Slovak Lutherans - Huguenot church architecture · cross symbol $\cdot$ Leonhard Christoph Sturm

\section{János Krähling}

Department of History of Architecture and of Monument Preservation, BME, 1111-H Budapest, Múegyetem rkp.3. K. 260., Hungary

e-mail: krahling@et.bme.hu

\section{Gergely Domonkos Nagy}

Department of History of Architecture and of Monument Preservation, BME, 1111-H Budapest, Múegyetem rkp.3. K. 260., Hungary

\section{Introduction, Research history}

The Greek-cross ground plan form with its elongated and extended variants is one specific church layout type of Hungarian Lutheran church architecture, of which we will provide an overview and an architectural analysis in this paper. On the one hand, the examination of these issues is interesting and justified because the publications dealing with the Hungarian Protestant church architecture seldom mention the Lutheran examples in connection with the central layouts that appear more rarely than those with a longitudinal arrangement and their prototypes as well as their usage can be traced back to Western European types ${ }^{1}$ while comprehensive European overviews of the Protestant church architecture in insignificantly few cases deal with Hungary and the region. On the other hand, the contribution might be important because of the continuity which is recognisable between the late Baroque and late $19^{\text {th }}$ century or early $20^{\text {th }}$ century Protestant church architecture in Hungary ${ }^{2}$, The paper aiming to elucidate from different viewpoints the occurrence and usage of the layout type in historic Hungary has been prepared within the framework of a comprehensive research 3

European architectural history writing dealing with the phenomenon and problems of evangelical churches with the layout in question is relatively rich; the limits of this study allow us only to hint at the most important references in terms of analogies and parallels to be dealt with hereunder. One of the standard works of European and German Protestant church architecture, the corpus of Karl Emil Otto Fritsch published in 1893 can be considered as a basis of the research issues [9]. The studies on protestant church architecture of J. Harasimowicz can be considered as fundamental contributions to the exploration of the layout type in his Central European contexts [12],[13].

The first historic and architectural analysis of Hungarian Greek-cross plan Lutheran churches with a theoretical claim had been laid down by Samu Pecz - although emphasizing that his

\footnotetext{
${ }^{1}$ See e.g. by the evaluation of the oval plan of the Lutheran church in Sopron: Winkler, G. 1978. [35. p. 173, 184]

${ }^{2}$ Cf. the "New Evangelical Church" at Szarvas and the 18. C. treatises as prototypes [36 p. XLI]

${ }^{3}$ Subsidised by the Hungarian National Research Fund, No. OTKA 68933.
} 
essay was only written in connection with the planning of the new church of Debrecen. In setting up a new system of Protestant church architecture in three groups he is looking for the base of his church plan in the third group that is the newly introduced Greek-cross layout which is independent of the more frequent longitudinal ones [27]. The first thorough typology of Lutheran churches in Hungary had been elaborated by Loránd Friedrich [8]. Among his four basic types the "German" one means the buildings more or less following the architectural principles laid down by L. C. Sturm, meanwhile the centrally planned types appear in the group of "circular or elliptical" [8, pp. 172-173]. As he outlines, the Greek-cross examples are special, he then deals with the churches of Békéscsaba, Késmárk (Kežmarok, Slovakia) and Kassa (Košice, Slovakia) mentioning for example the church of Kassa (Košice) the exemplary role of the Karlskirche in Vienna and S. Carlo alle Quattro Fontane in Rome.

According to the researches of István Bibó the central evangelical churches at Maglód and Domony situated on the edge of the Great Hungarian Plain are exceptions among Protestant churches with a typical longitudinal arrangement, and these longitudinally arranged churches represent the local tradition and therefore are in the majority in contrast to those centrally arranged that are more frequent in Europe [2, p. 528]. In the case of the church of Maglód and Domony - argues Bibó - the explanation is given by the fact that this congregations settled here from Upper Hungary (today Slovakia) where the protestants who were mainly Lutherans - much more frequently used central or centralizing T-shaped arrangements [2, p. 529]. Ernő Marosi emphasizes by the churches of Békéscsaba and Domony, the exceptional independent architectural efforts alone appearing here among the tendencies of Protestant church architecture in Hungary following the Upper Hungarian tradition of the church of Késmárk (Kežmarok)[23]. István Bibó devoted an analytical study to the Hungarian Protestant church architecture in the time around 1800 - which is one of the most intensive and rich periods - characterising it with the majority of the longitudinally arranged plans and subdividing them into two sub-groups: the towered "Big churches" - mainly of Calvinists - typical for the Great Hungarian Plain and that of the hall churches without tower - in the deciding majority of Lutherans - of Western Hungary [2] $]_{4}^{4}$ The centrally planned Lutheran churches of Upper Hungary appeared in the course of the examination of those of South Transdanubian as an independent group and as a sharp alternative [17, 18]. Gábor Winkler devoted a separate chapter to the centrally planned layouts in his summarising study of 1992 reviewing the Lutheran church architecture in Hungary and in his own thoroughness, also analysed the Greek-cross plan types with the examples of Késmárk (Kežmarok), Maglód, Domony and Békéscsaba [36, p. XXXV]. On the basis of a comprehensive survey of the evangelical churches in today's Hungary it

\footnotetext{
$4 \sqrt{3}$ p. 2], (1985) The centrally planned types are not detailed and their origin is determined by the effect of German Protestantism.
}

was possible to outline a more typology [15].

In the works discussing the architecture of Hungarian reformed churches - because of the lack of late Baroque central spaces - mostly $19^{\text {th }}$ century centrally arranged layouts appear 5 István Medgyaszay separately deals with the Greek-cross plans at the beginning of the $20^{\text {th }}$ century [25]. János Schulek initially mentions the central ground-plans in the renewal of the Reformed church style of the $20^{\text {th }}$ century [30]. Enikô Róka briefly reviews in the monograph of the Reformed church of Buda (Szilágyi Dezsô tér) the central antecedents also the Hungarian Greek-cross plan churches [29]. Zoltán Lórincz emphasizes through the overview of the central prototypes in his book presenting the Reformed church architecture in Hungary of the 1990s the role of central Huguenot temples serving as a model [22].

\section{The cross symbolism in the Protestant church archi- tecture}

The devotion of the Lutherans to the form of the cross can be interpreted in the broad tendency of the visual arts which is characteristic for its didactic teaching and commemoration defining also the principles of Luther in the arts [21, p. 37]. It is obvious that the form of the cross hints at the most important and principal event in the salvation story of Christian - and within that, Lutheran - faith, on the crucifixion of Christ and through it the redemption from sin. The typical Lutheran attitude on the symbolism of the cross had been formed in the faith debates of early Protestantism stating that the cross meant the freeing of the law of the Old Testament prohibiting "image carving" [28, p. 200] and at the same time is the basis of the Greek-cross spatial symbolism. The first reformers following Calvin's tradition initially - accepting the proposal of the reformer of Strasbourg, Martin Bucer - considered the central ground plan as a primary one, considering its classical origin and therefore worthy to follow parallel with the same origin of the longitudinal ones deriving from the antique basilica [26, p. 205]. Centrality also symbolises in this context the community of the Lord's Supper of the early Christian church, as well as the intimate unity of the prohibited meetings. The form of the cross has been consistently neglected by the Calvinists, and even the altar cross appeared only from time to time and later from the middle of the 20th century [28, p. 204]. The extraordinary link between the symbolic content of the cross form and the Lutheran church as an architectural unit can be recognized in the custom more typical in Europe but less so in Hungary that churches are named continuing the medieval tradition of the patrocinium; in the majority of cases the most frequent names are Christ-, Redemption, Redeemer or Saviour and Cross Churches. However, the symbolic interpretation of the ground-plan of the church had already become a common part of the architectural thinking before the ref-

5 [25]; 24. pp. XXVI-LVI] The extension of the reformed church at Dunavecse (built 1743-45) to a cruciform layout in 1808-1810 is rather a later exception. Thanks to István Bibó for his kind help. 


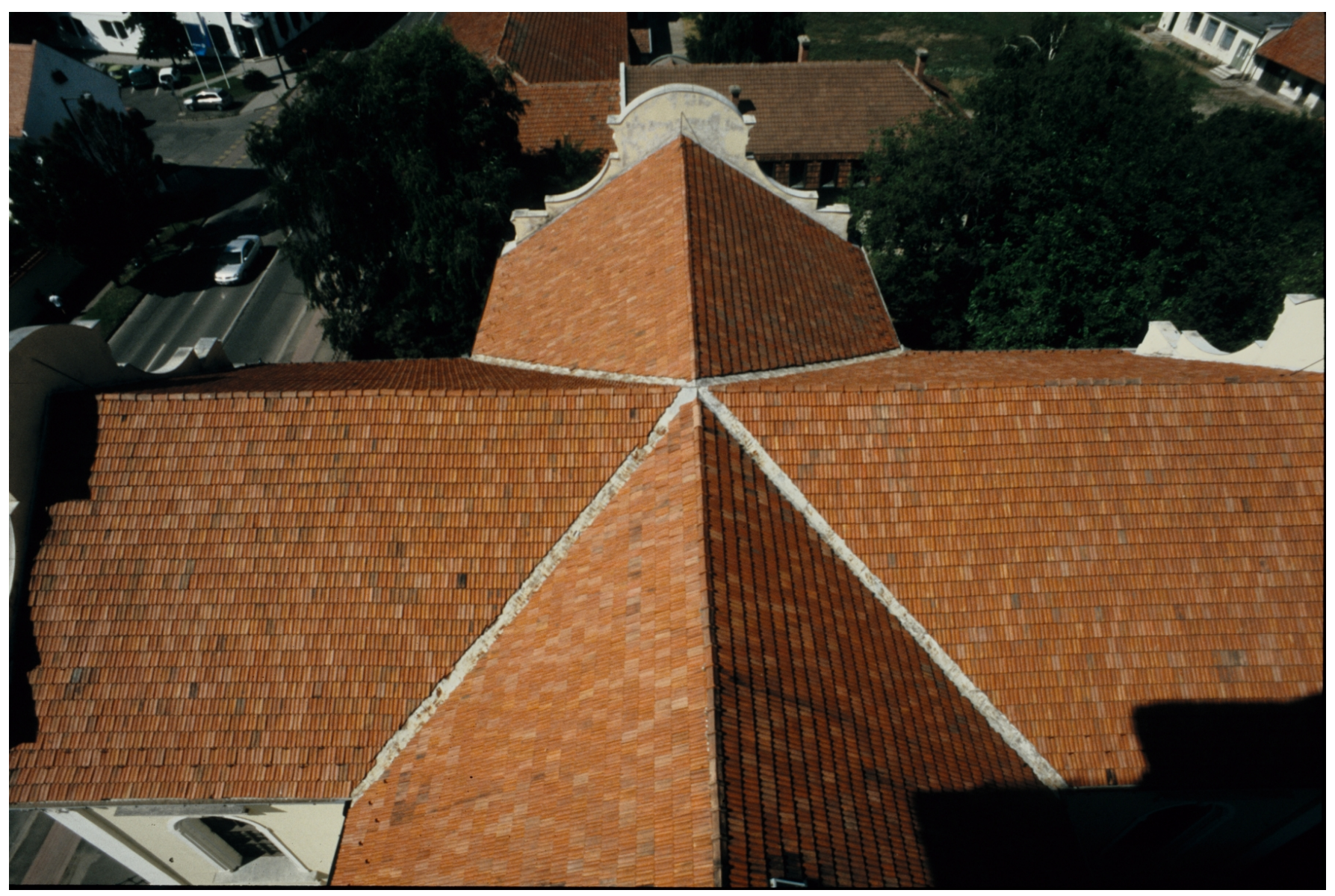

Fig. 1. The aerial view of the "Small Church" at Békéscsaba

ormation, in the architectural theory of the Renaissance which had taken the classical philosophy as a basis. Centrality, or more scrupulously, the circle as the "perfect form" is the symbol of God and the (Latin) cross layout the symbol of the crucified Christ, are at the same time the manifestations of an anthropomorphic architecture based on Vitruvius.

\section{The influence of Huguenot church architecture}

The central types of the European Protestant church architecture can chiefly be originated from the Huguenots. The painting depicting one of the former Lyonese Huguenot temples, the Temple de Paradis (built in 1564, demolished in 1567) illustrates one of the standards of centralising interior spaces. This building was a privately-owned oratory which was later transformed into a church [11, p. 142]. The central temples at Dieppe and at Bourg-l'Abbé close to Caen had already been newly built and the one at Petit-Quevilly beside Rouen with its dodecagon plan is the example of early Protestant church architecture experimenting with the layout. However, there was no Greekcross plan temple among the early Huguenot central layouts [5. p. 185].

Beside the central shaping of these spaces they are also instructive from the point of view of their construction having been made partially or completely of wood according to the regulations of the Edict of Nantes, the construction of which is an important prototype in the terms of our topic since the building

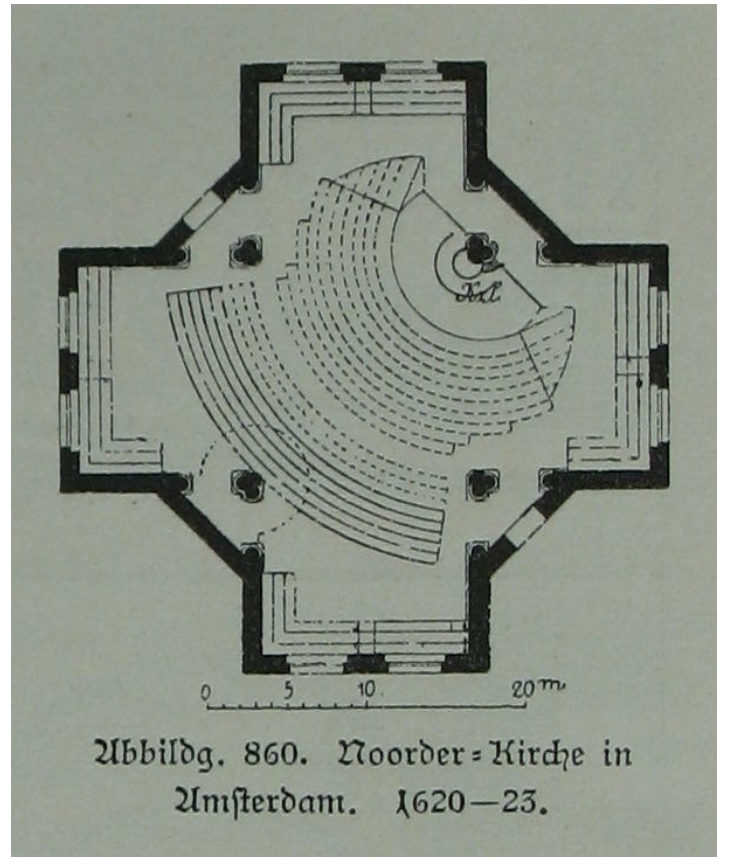

Fig. 2. Amsterdam, Noorderkerk (1620-23) ground plan (After Fritsch 1893.)

of "Articular churches" were essentially restricted according to similar principles 6

\footnotetext{
6 "Articular church" (or "articled church") architecture refers to the period between 1681-1781 when the building of Protestant churches in Hungary were allowed only on sites determined by legal articles (articulus) as well as their size
} 
The early monuments of the Greek-cross form can be found on Huguenot influences - in the Netherlands (Amsterdam, Noorderkerk 1620-23; Maaslouis 1629-39 and others) which could have served as models for the Protestant regions of Europe mediated by the students being attracted to the local Dutch Protestant universities - as in Copenhagen (Church of Holmen, 161941; Church of Our Saviour 1682-94), in Stockholm (Katarina Church, 1656-70) and in Berlin as well as the so called "Friedenskirche" churches (Church of Peace) in Silesia after the Peace of Westphalia and perhaps initially the church at Schweidnitz (Świdnica, PL. built 1657-58) with its cruciform ground-plan [12, p. 337]. From the point of view of our investigation the Schweidnitz (Świdnica) church may have served as a primary model.

\section{The influence of Leonhard Christoph Sturm}

The architectural theory of Leonhard Christoph Sturm cannot be neglected in the course of this essay, the effect of whom on the evangelic church architecture of the $18^{\text {th }}$ century cannot be overestimated. He published the first theoretical analysis of Greek-cross plan evangelical churches under various considerations of the phenomenon. In his booklet of 1712 - which is in fact an expert opinion on the continuation of a church building started according to a plan laid down in the form of an equal cruciform - he published a rich typology of variations of protestant churches other than the Greek-cross plan [31]. Later in his lengthier treatise of 1718 he explains these Protestant model plans in much more detail and draws at the same time a parallel with the Catholic church architecture [32]. Sturm writes in his 1712 work that the Greek-cross ground-plan has been for a long time so much beloved by the Protestants especially by the Lutherans, that he can write it down only with a fear that architecturally it is the most inappropriate one [31, p. 2v]. For this inappropriateness he gives several reasons: it is possible with the amount of construction material used to establish much more room in case of another ground-plan form (and also gives examples for this), by the analysis of the functional layout he mentions that the pulpit is not always visible, the frittered building mass does not give a worthy expression to the church, the illumination of the crossing appears to be problematic, his roof leaks often because of the valleys, and he argues finally, that the cross form - although maybe even of early Christian origin - is not absolutely and exclusively exemplary for a Christian church [31, pp. 3v-5r]. Among the proposed forms for the layout he judges Plate III. - a Greek-cross arrangement resulting from the extension of a square - from the viewpoint of the incoming light as well as in terms of the inner traffic much more favourable, though since it is similar to the Greek-cross however, he assumes that the asymmetric arrangement of the pulpit

and the building materials and techniques to be used. The articuli XXV. and XXVI. of the parliamentary session held in Sopron in 1681 determined these restrictions in the building activity of the non-Catholics in Hungary which the "Articular churches" are named after. Cf. [6] and the visual and acoustic conditions spoil the value of this ground-plan. It should be noted that this ground-plan mediates mostly that central space organization model - with its longitudinal arrangement inside the cross, his asymmetric pulpit placement and with his stairs placed at the end of the arms of the cross as well as the tower at the axis before the façade - which was followed by the churches built in Hungary especially by the time of the Edict of Tolerance. The plan variant on Plate IV is also close to the form of the Greek-cross space layout with its octagonal origin; the lighting also seems to be more convenient but on the other hand the position of the manorial gallery and its disposition is inappropriate in terms of comfort. The expertise finally suggests keeping the Greek-cross plan depicted on Plate IX because of economical reasons however with a longitudinal transformation of the interior and with a tower in the longitudinal axis and similarly a pulpit placed on the symmetry axis before the main altar at the borderline between the crossing and the sanctuary. These arrangements with the pulpit in the foreground of the main altar will be one of the main architectural solutions of the new liturgical spaces in the $19^{\text {th }}$ and $20^{\text {th }}$ centuries returning in the church designs of Karl Friedrich Schinkel and Otto Bartning.

Sturm analyses in his work of 1718 , Protestant church architecture, comparing it with that of the Catholics and pays special attention to the components, emphasising the sanctuary and its differing role. He observes that the cruciform is especially suitable for the large Catholic churches, but mistakenly, the designers of Protestant churches believe the same of him. Its benefit is that it keeps the most important object of the sermon constantly in view, but the effect of this is insignificant or rather negative and therefore it does not provide enough reasons to build an uncomfortable and less stable building at greater expense [32, p. 31]. On Plate XIV he publishes a possibly suitable Greek-cross ground plan with furniture inside and not over criticizing the form, because as he states, with his 1712 expert opinion he made many enemies [32, p. 39]. The essays of Sturm reflect the German architectural public opinion of that period, and in terms of the spreading of the ground-plan form elaborated above seem to be fundamental for their works rejoicing at a relatively big occurrence. We can hear the echo of his works in the development of the European Protestant church architecture of the $18^{\text {th }}$ century, with which he not only influenced the designs of representative buildings like the Frauenkirche at Dresden but equally the smaller regions with their minorities, so his effect on the East Central European region in question also cannot be excluded [12, p. 342] [13, pp. 99-103].

\section{The Silesian Greek-cross ground-plan spaces and their effect}

The previously mentioned Lutheran church at Schweidnitz (Świdnica, Poland, built 1657-58) had been designed by the military engineer Albrecht von Saebisch from Breslau (Wroclaw), who might have studied the tendencies of Protestant church ar- 

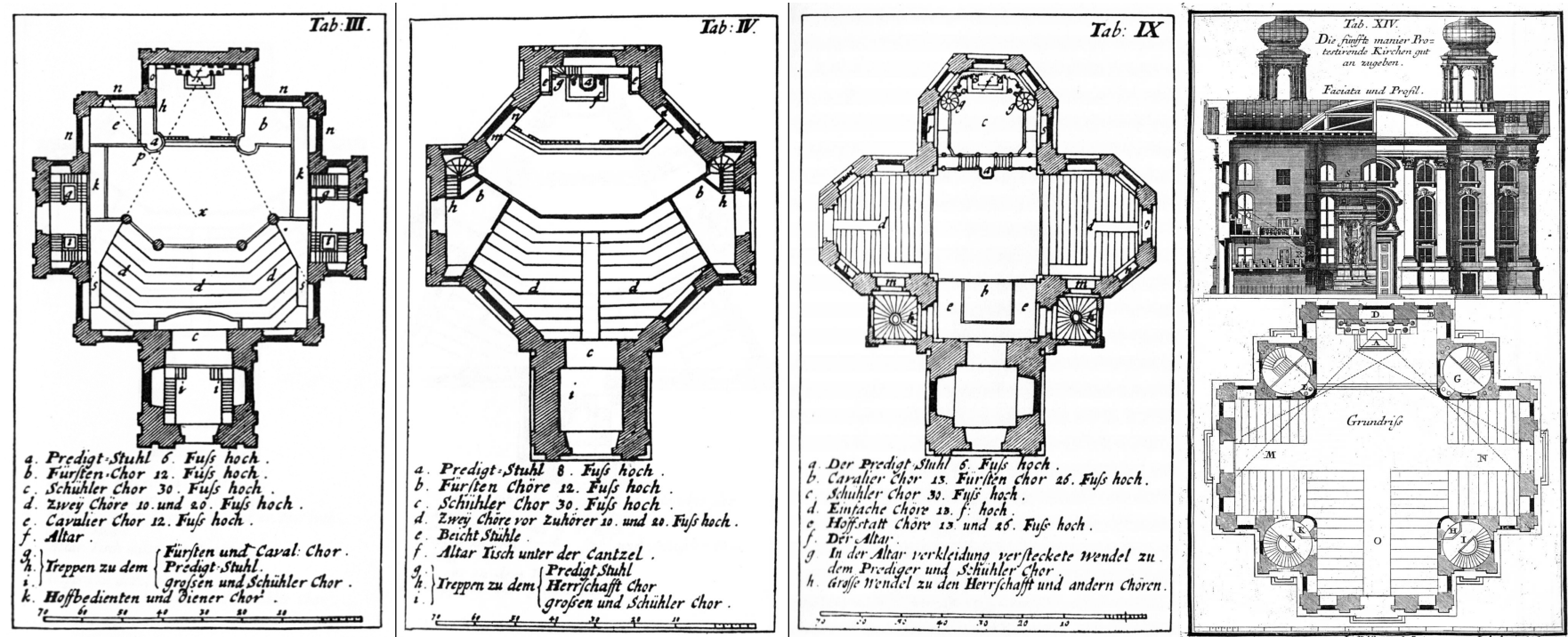

Fig. 3. Greek-cross ground-plan churches of Leonhard Christoph Sturm; Plates 1712/III; 1712/IV; 1712/IX; 1718/XIV.

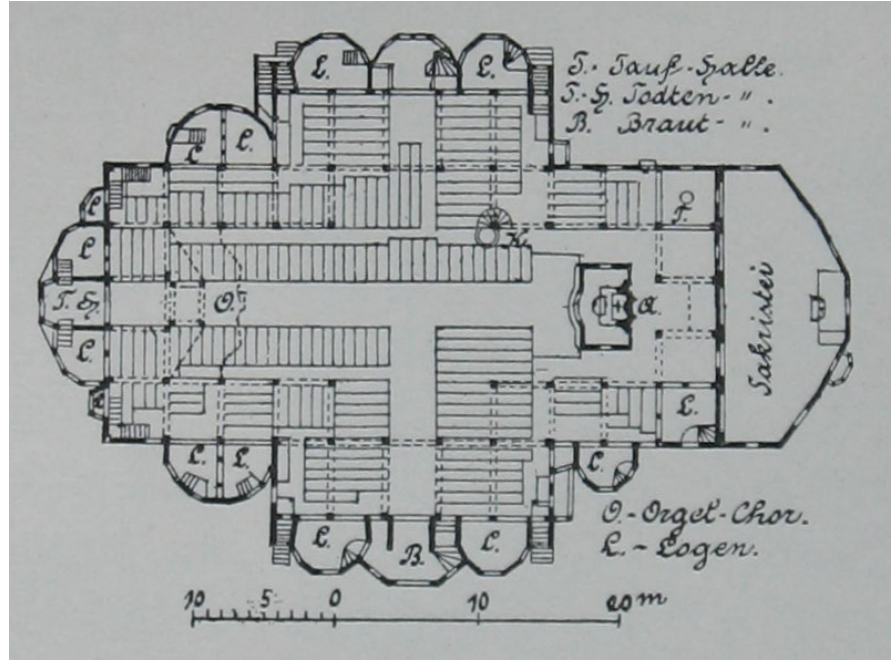

Fig. 4. Schweidnitz(Świdnica) Ground plan of the Lutheran church built in 1657-58. (After Fritsch 1893.)

chitecture on his journeys to Western Europe [4, p. 89]. Saebisch chose the elongated Greek-cross plan for the Schweidnitz church consciously by which - following his argument he might have both fulfilled the visual and acoustic requirements of the sermon and the stability requirements of the building [9. p. 60]. By the architectural conception he determined the proportions of the interior space according to the treatise of Furttenbach published in 1649 [4. p. 107]. The structure of the Schweidnitz church, the huge timber construction created with his renowned knowledge of carpentry later played a similarly considerable role by serving as a model. The later built Silesian churches did not follow the plan solutions of Sturm since these were published later, but for them the Katarina Church in Stockholm (designed by Jean de la Vallée, built 1656-1670 in the cruciform) served rather as a prototype. The so called "Gnadenkirche" buildings (Church of Grace) like the one at Hirschberg (Jelenia Góra, Poland, 1709-18) and at Landeshut
(Kamenna Góra, 1709-30) erected after the peace treaty of Altranstädt (1707) after the plans of Martin Frantz master builder from Tallinn definitely also contributed to the spreading of the cruciform in East Central Europe [12. p. 343].

\section{The relationship of the liturgical function and the inte- rior space}

Through the symbolism of the cross we mentioned that the central space layout excellently meets the requirements of the Protestant ceremonies. However, it would be superficial to state that this merely derives from the importance of the sermon. Preaching had already become an important factor in the shaping of the church interiors of the mendicant orders founded in the $13^{\text {th }}$ century, but this did not result in centrally planned churches at all, and we also cannot claim of the Catholic Church after the Council of Trent that the sermon had been neglected in its liturgical practice. For the importance of the preaching, the pulpit remained in the main axis of the building in the Lutheran churches.

The differences between Catholic and Protestant liturgical functions can be traced back to two important features: first of all Catholic churches can be characterized by the continuous presence of the sacrament, and secondly, by the differences in the interpretation of the effect of grace of their own liturgies. The fundamental spatial orientation of the believers in a Catholic church is determined in the turning towards the Eucharist which is the "target" of the adoring worship. According to the Lutheran approach of the Holy Sacrament, Christ is substantially present by taking the Lord's Supper although not continuously in the wafer and therefore the importance of the altar decreases within the church service and is not the "object" of the religious homage. The act of the Protestant worship by itself is also not merely of sacramental character and the act of the Lord's Supper is of a rather commemorative character than having a real share in Christ's sacrifice. According to the teaching 
of Luther, salvation is the fruit of the faith that presupposes the confession of the sins and which comes from the "free" grace of God on the price of the crucifixion and redemption of his own son. It is to underline that the reformers rebelled just against the practice of the late-medieval church that tried to make man's salvation dependent on a human activity, yet if it is just the liturgical prayer. However, in this approach the character of the worship - its act in and beyond itself - is reinterpreted and its key position has ceased in the salvation of man. This reinterpretation resulted at the same time as the community character of the worship - like the common sermon of all of the congregation's believers for example - and yielded proportionally a considerable increase in the role of the pulpit in the interior of the church.

The Greek-cross plan churches in historic Hungary till 1800

The oldest cross plan Protestant churches in Hungary have been built for the Slovak congregations in Upper Hungary on the so-called "articular sites" and one of their main common characteristic features is the use of the Greek-cross plan or its modified version 7 The churches at Hybe (Slovakia, built 1686-87, rebuilt 1786-1787 and modified 1822), [19. pp. 142-143],[33, p. 1/429], Nagypalugya (Vel'ká Paludza, Slovakia, built 1693; 1774, the church transferred to Svätý Kríž) [1, pp. 26-30], Késmárk (Kežmarok, Slovakia, 1717) [19, pp. 90-93], [33, p. II/40], and Garamszeg (Hronsek, Slovakia, 1725-26) [19, pp. 84-87] [33. p. I/457] were built of wood, their interiors are covered with Tunnel and Groin vaults and the number of the seats had been increased by the galleries. We can already recognise here the later general arrangement by which the altar appears in one end of the cross-arms and the pulpit on one pier of the crossing. At Isztebnye (Istebné, Slovakia, built 1686, enlarged 1730) [19. pp. 88-89][33, p. I/494] and at Lestin (Leštiny, Slovakia, 1688) [19, pp. 94-97][33, p. II/185] churches with elongated Greek-cross plans had been realised in a more plain form following the layout of the previous churches. The "Articular churches" lying south of the then Hungary like at Nemeskér, Nemescsó and Nemesdömölk (today Celldömölk, Hungary) did not follow the cruciform arrangement but rather the longitudinal layout which characterizes them. The different character in the ground plans had been influenced not only by the diverging local traditions but also in the differences of the local county regulations.

In the period just before the Act of Tolerance (1781) some new cruciform plan churches were erected on the area of today's Hungary. The church without a tower at Maglód was built in 1776 and the nearby church at Domony in 1777 and the socalled "Small Church" at Békéscsaba was expanded to a Greekcross plan in 1773.[10, p. I/38]The elongated cruciform church at Toporc in Upper Hungary (Toporec, Slovakia, 1767-70) had also been built in this period [19, p. 193] [33, p. III/292] .

The Act of Tolerance allowed Protestants a bigger freedom to build their own churches which consequently resulted in an

\footnotetext{
${ }^{7}$ For the "articular sites" see 1 . pp. 26-30] and Note 8.
}

enormous building activity. The most monumental late baroque churches of this building type had been erected in this period, that of Miskolc (built in 1797) with its fascinating dimensions and that of Gölnicbánya in Upper Hungary (Gelnica, Slovakia, built 1784) as well as the church at Igló (Spišská Nová Ves, Slovakia, 1790-96) with its good architectural proportions ${ }^{8} \mathrm{We}$ may recognise the development of a peculiar "building type" in Szepesség (Spiš, Slovakia) in Upper Hungary which shows the effect of the cruciform plan "Articular churches". Constituted of three bays in a longitudinal arrangement the middle bay appears wider than the others and this appears also in the exterior mass like the reduced arm of a cross, as in churches of Mateóc (Matejovce), Merény (Nálepkovo), Strázsa (Stráže pod Tatrami), Szepesbéla (Spišská Belá), Szepesszombat (Spišská Sobota), Szepesváralja (Spišské Podhradie) and Szepesolaszi (Spišské Vlachy).

In many cases Lutherans began to use the medieval church of the settlement. At Cinkota (by Budapest) and at Kistorony (Neppendorf in German , Turnişor by Sibiu, Romania) a new Latin-cross plan church was built using the former medieval wall structures [20, pp.I/409-410].

The cross layout system appears in the Lutheran church architecture of the later periods, especially alloyed with the design principles of Classicism. The churches at Besztercebánya (Banská Bystrica, Slovakia, built between 1803-1807) [33, p. I/58] and at Kassa (Košice, Slovakia, built between 1816-1820) [33, p. II/102] with oval cupola over the crossing show reminiscences of the Baroque architectural principles, but their details already point towards Classicism. The Greek-cross plan churches at Körmöcbánya (Kremnica, Slovakia) and Lőcse (Levoča, Slovakia) [19, pp. 152, 154-155] are much more purely Classicist creations.

Regarding the centrally planned Lutheran churches it is hardly possible to find arrangements other than the cross layout. The Saxon settlement in Transylvania, Malomárka (Minarken in German, Monariu, Romania) is supposed to follow the circular layout because of a local tradition [16].

The leitmotif of the interior space of the large-scale Classical late Baroque evangelical church at Selmecbánya (Banská Štiavnica, Slovakia)[19, pp. 118-119] [33, p. 1/76] built between 1794-96 after the plans of Joseph Tallherr is the oval dome to which besides the entrance and the chancel six additional semicircular spatial expansions divided by galleries are attached. The small church at Nemesváralja (Zemianske Podhradie, Slovakia) [19, p. 198] [33, p. III/465] built between 1784-1801 is the marvellous result of the art patronage of the aristocrat. Its threecentred arches are yet the reminiscences of the Baroque taste, but the space organization imitating a peristyle is already unambiguously Classicist.

Observing the nationalities of the mentioned settlements we

${ }^{8}$ Gelnica: [19. p. 133], Spišská Nová Ves: [19 pp. 182-183], 33 p. III/155]; for Miskolc see [34 pp. 24-26] 

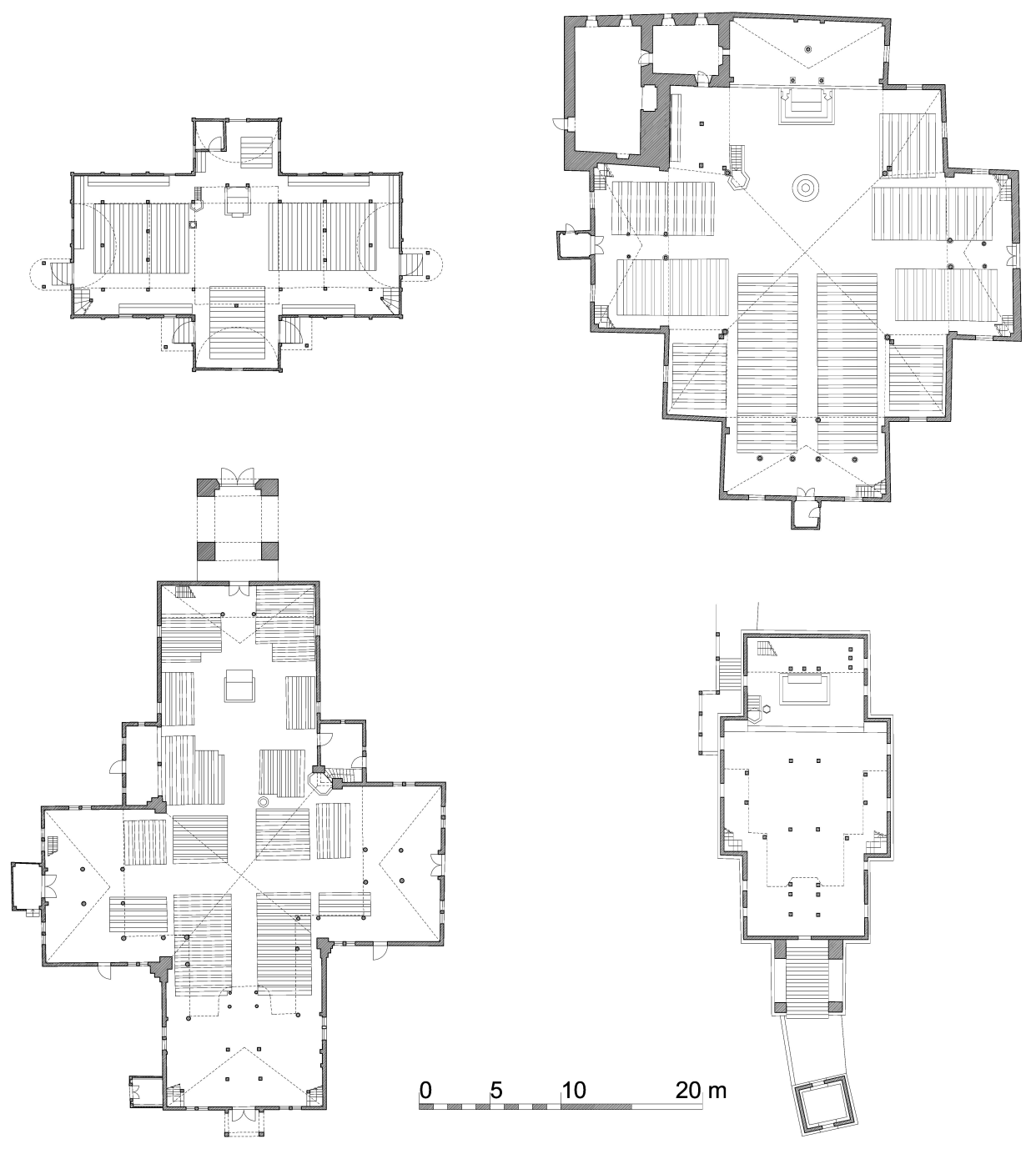

$\begin{array}{lrrr}0 & 5 & 10 \quad 20 \mathrm{~m}\end{array}$

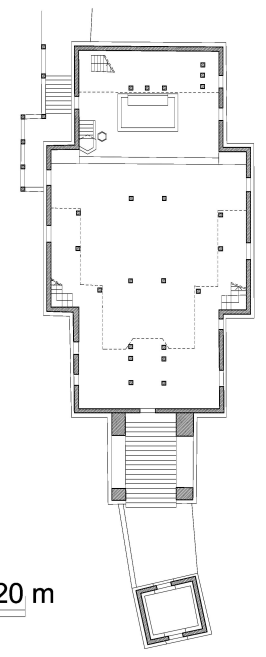

Nagypalugya / Vel'ká Paludza

Lestin / Leštiny

Fig. 5. Ground plans of "Articular churches" of Upper Hungary

can make some interesting remarks, the work of Elek Fényes published in the 1830s offers a good opportunity for this investigation [7]. The settlements of the "Articular churches" of Upper Hungary were clearly of Slovak nationality. According to the data of Fényes, 17] 9 Maglód was a Slovak settlement at the beginning of the $19^{\text {th }}$ century with a considerable Jewish minority. Cinkota was a Slovak-German village with according to him, a Slovak majority. Domony - similarly to Maglód was a village with a Slovak majority but with considerable Hungarian and Jewish minorities. Miskolc was already a populous city at this time with nearly 27,000 inhabitants and with several nationalities, among which - after the Hungarians and the Ger-

\footnotetext{
${ }^{9}$ Slovak village with 675 Lutheran, 263 Catholic, 225 Jewish, 10 Calvinist inhabitants.
}

mans - the Slovaks were in third place, on the other hand in the Lutheran congregation they were in a slight majority with more than one third vs the Hungarians and Germans with their almost equal but lesser thirds in the parish. The Slovak nationality of Békéscsaba is well-known; the Lutheran Slovak settlers came to the village in Gölnicbánya (Gelnica, Slovakia) which was at that time a mining town with a mixed Slovak and German population.

Is manifest from the data above that practically all cross plan church have been built by a Slovak community or with its majority in the congregation. Of course this does not mean that all Slovak evangelic communities would have elected this form for their church buildings and at that time beside the Slovaks, there was also a considerable German and lesser Hungarian minority 

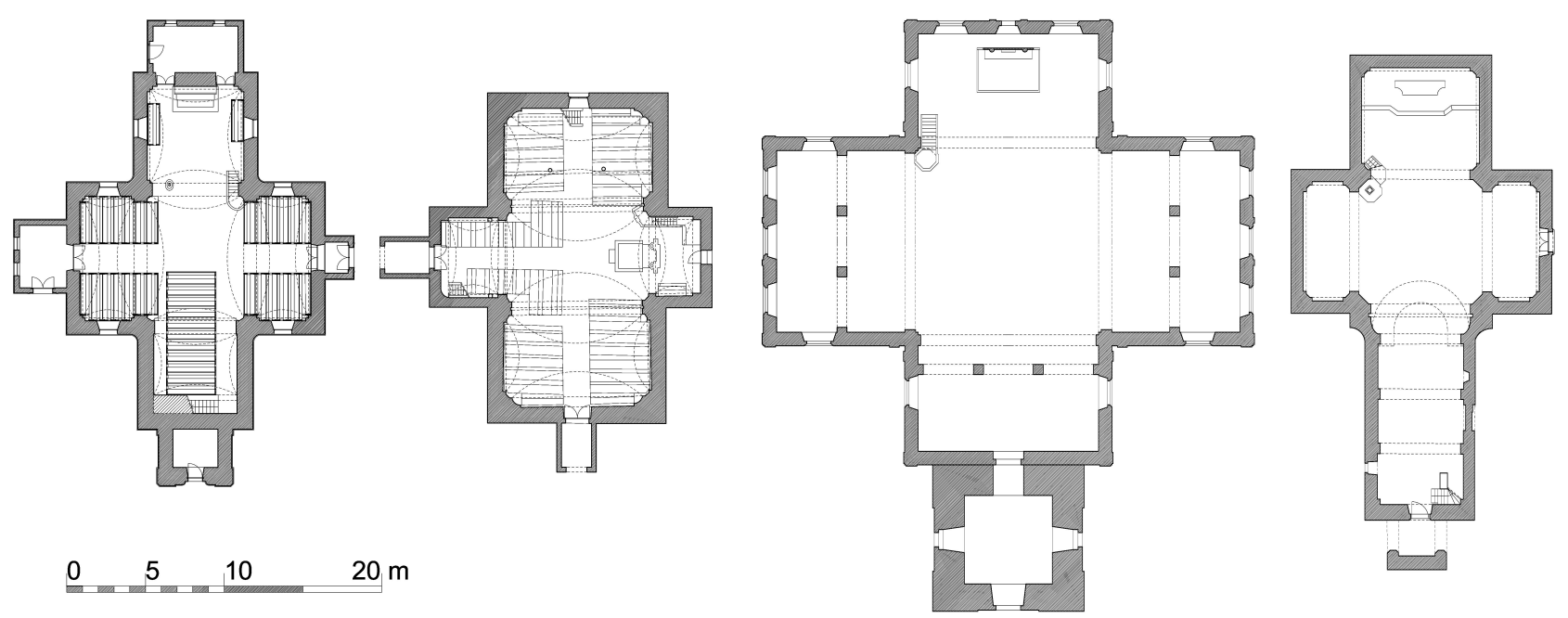

\section{Domony \\ Cinkota}

Fig. 6. Greek-cross plan Lutheran churches built before the Act of Tolerance (1781) in Hungary

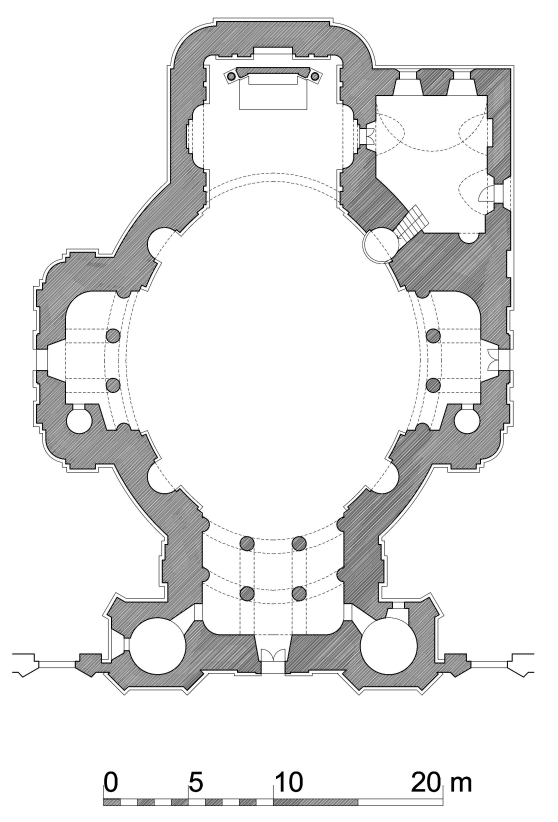

Kassa / Košice

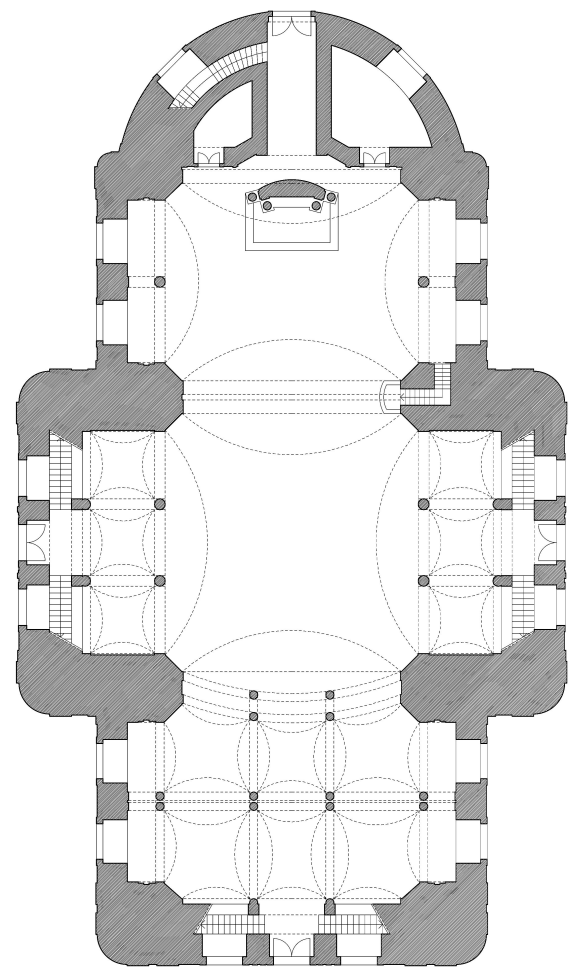

Igló / Spišská Nová Ves

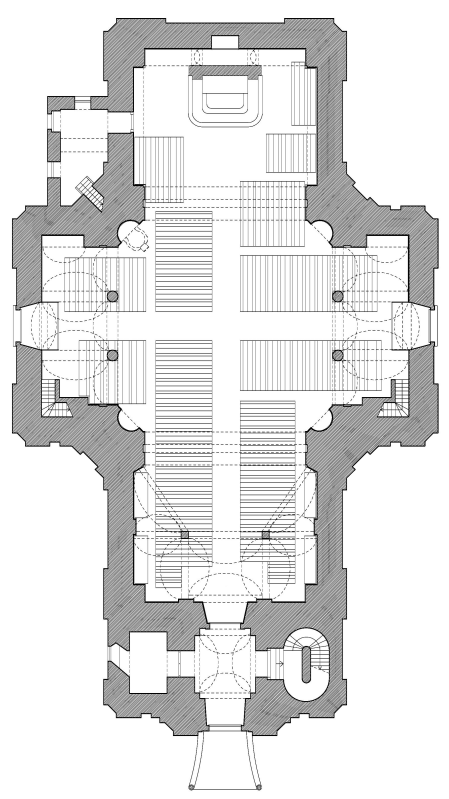

Miskolc

Fig. 7. Greek-cross plan Lutheran churches built after the Act of Tolerance (1781) in Hungary

among the Lutherans in Hungary who followed in their church architecture the longitudinal tradition. The usage of the Greekcross form in the ground-plan appears as an exclusive church ar- chitecture tradition of the Slovak Lutherans of Upper Hungary. It might be possible to analyse whether one of the most determining spiritual movements of Lutheranism in the $18^{\text {th }}$ century, 
the pietism might have played a role in the formation and spreading of this church layout. Taking the churches' position and the circumstances of their erection into consideration it might be probable that pietism influenced it in general [13] as much as faith can play a motivational role, but actually on the "Articular sites" and in towns - Késmárk (Kežmarok), Garamszeg (Hronsek) and Nagypalugya (Vel'ká Paludza) - pietism was not accepted so may not have been the motivator. The contrary of this could be true although this is also not provable; in the Western central area of Hungary, in Transdanubia where the principal centres of pietism in Hungary can be found just the traditional longitudinal layout churches are typical [6].

\section{The connection of structure and space}

In the case of the cross ground-plan "Articular churches" the most important space characteristics were determined by wood as the principal construction material; however the usage of wood occurred not independently but followed the limiting regulations. On the one hand it is very problematic to construct a curved wall structure of wood and there is an upper limit primarily determined by the practice for the longitude of the beams on the other. Following this principle the straight wall sections forming a Greek-cross with a central arrangement - were easily achievable and even with multiple right angle extensions - as in the case of Késmárk (Kežmarok) - the spacious inside may have been realised of relatively short beams, with this solution also increasing considerably the stiffness of the wall construction. Following the argument of Sturm it is absolutely correct that by the cross ground-plan with a relatively narrow span distance a much bigger interior can be achieved where the believers may have seen the pulpit and may have more clearly heard the pastor.

\section{Summary}

At the end of our discourse we have to answer the question whether Catholic churches influenced the architectural formation of the examined Hungarian evangelic churches. We hinted at the problem by the analysis of the liturgical aspect that in traditional Catholic church layouts the centralising tendencies appear controversial. Although there are several cross layouts amongst that of the Hungarian ones (like the Catholic churches of Nagykőrös, Tósokberénd, Miklósfa) and we may see parallels in the symbolic interpretation of the cross form like at Balatonkeresztúr, Bakonyszentlászló, Püspökszentlászló, Nagykanizsa - we are inclined to think that these did not affect directly the church architecture of the Lutherans in Hungary.

The usage of the cross ground plan in the Lutheran church architecture has been the result not merely of its symbolic content or of its appropriate space structure easily adjustable to the needs of the liturgy.

We pointed out earlier that the churches being built in the time of the Act of Tolerance have antecedents in wooden architecture, in the mediation of which towards the southern regions the Slovak Lutherans played a determining role.

The late Baroque Greek-cross plan layout is indeed an antecedent and forerunner of the development in the architectural space which blossomed out by the re-intertwining of Lutheran and Calvinist church architectures at the end of the $19^{\text {th }}$ century in Historicism. The principle of centrality yielded new architectural solutions in the architecture of Miklós Ybl, Samu Pecz, Frigyes Schulek and Gyula Sándy.

In our contribution we touched on several minor problems of the issues that have already sporadically appeared in the works of other researchers, however, the re-overview, analysis and the responses to these questions as well as their reintegration into the main European tendencies may not be worthless. It may enrich our knowledge on the cultural connections in the Eastern Central Europe of the $17^{t h}-18^{t h}$ centuries that played an important role in the development of the region and to which this specific Protestant culture was able to contribute.

\section{References}

1 Biathová K, Drevený panteón, Tatran, Bratislava, 1976.

2 Bibó I, Az Alföld késóbarokk és klasszicista építészetének néhány kérdése., Építés- és Közlekedéstudományi Közlemények (1967), no. 3-4, 525-567.

3 , Der protestantische Kirchenbau in Ungarn um 1800, Mitteilungen der Gesellschaft für Vergleichende Kunstforschung in Wien 37 (1985), no. 3 , 1-5. and.

4 Borrmann M, Evangelische Friedenskirchen in Jauer und Schweidnitz, 1991, pp. 87-118.

5 Coope R, Salomon de Brosse and the Development of the Classical Style in French Architecture from 1565 to 1630, A. Zwemmer Ltd, London, 1972.

6 Csepregi Z, Magyar pietizmus 1700-1756, Teológiai Irodalmi Egyesület, Budapest, 2000.

7 Fényes E, Magyarországnak 's a' hozzá kapcsolt tartományoknak mostani állapotja staistikai és geographiai tekintetben, Vol. 1-6, Trattner-Károlyi nyomtatása, Uri utcza 612. szám., Pest, Unknown Month 1836.

8 Friedrich L, A magyar evangélikus templom fejlödése az újkorban, Evangélikus templomok (Kemény L, Gyimesy K, eds.), Athenaeum, 1944, pp. 169192.

9 Fritsch K E O, Der Kirchenbau des Protestantismus von der Reformation bis zur Gegenwart, Berlin, 1893. Herausgeben von der Vereinigung Berliner Architekten.

10 Genthon I, Magyarország múvészeti emlékei, Vol. I-III, Képzőmúvészeti Alap Kiadóvállalata, Budapest, 1961.

11 Guicharnaud $\mathbf{H}$, An Introduction to the Architecture of Protestant temples Constructed in France before the Revocation of the Edict of Nantes, Visual Arts and the Calvinist Tradition (Finney P C, ed.), William B. Eerdmans Publishing, Grand Rapids Michigan/Cambridge, 1999, pp. 133-161.

12 Harasimowicz J, Protestantischer Kirchenbau im Europa des 17. und 18. Jahrhunderts, Religion und Kultur im Europa des 17. und 18. Jahrhunderts. (Mainzer Studien zur Neueren Geschichte 12.) (Hartmann PC (with the contribution of Reese, ed.), Peter Lang Verlag, Frankfurt, 2004. first ed.

$13 \ldots$ _ Der Pietismus und der evangelische Kirchenbau der Frühen Neuzeit im kontinentalen Europa, Interdisziplinäre Pietismusforschung. Beiträge zum Ersten Internationalen Kongress für Pietismusforschung 2001 (Sträter U, ed.), 2005, pp. 83-105. Bd. I.

14 Harmati B. L, Késóbarokk szószékoltárok, oltárképek és festett karzatok a dunántúli evangélikus templomokban, 2006. PhD Disszertáció, kézirat (Phd Thesis, manuscript) ELTE Bölcsészettudományi Kar. 
15 Krähling J, Építészettörténeti áttekintés, Evangélikus templomok Magyarországon, sorozat III. Lutheran church in Todays Hungary, Series III, pp. 15-19. Architectural History Overview.

16 Kovács A, Malomárka evangélikus templomáról, Romantikus kastély (Vadas F, ed.), Hild-Ybl Alapítvány, Budapest. Tanulmányok Komárik Dénes tiszteletére, 2004, pp. 103-107.

17 Krähling J, South Transdanubian Late Baroque Church Architecture, Periodica Polytechnica Ser. Architecture 36 (1992), no. 1-4, 175-180.

18 _ “ "Veszendó templomaink” III., Budapest, 2004.

19 Krivošová J, Evanjelické kostoly na Slovensku, Tranoscius, Liptovský Mikulás, 2001.

20 Léstyán F, Megszentelt kövek, Vol. I-II., Gyulafehérvár, 2000.

21 Lörincz Z, "...die Bilder sind von uns genehmigt..." Die Stellung der ungarischen Reformation zur Kunst und zur Architektur., Concentrum, Stadtschlaining, 2002.

22 _ Ne hagyjátok a templomot..."- Új református templomok., Kálvin, Budapest, 2000.

23 Marosi E, Magyar falusi templomok, Corvina, Budapest, 1975. 2nd edition.

24 Dercsényi, Hegyi, Marosi Ernő, Takács, Magyar református templomok - múvészettörténeti áttekintés, Református templomok Magyarországon, Vol. XXVI-LVI, Hegyi\&társa Kiadó, Budapest, 1992.

25 Medgyaszay I, Templomstílusok, Magyar református templomok I-II. (Kováts J I, ed.), Athenaeum, 1942, pp. 15-67.

26 Mentzer R A, The Reformed Churches of France and the Visual Arts, Visual Arts and the Calvinist Tradition (Finney P C, ed.), William B. Eerdmans Publishing, Grand Rapids Michigan/Cambridge, 1999, pp. 199-230.

27 Pecz S, A protestáns templomok építéséról, kapcsolatban a debreceni kálvinista új templom részletes ismertetésével, A Magyar Mérnök- és Építész Egylet Közlönye 22 (1888), 193-205, 241-251.

28 Reymond B, L'architecture religieuse des protestants, Labor et Fides, Genève, 1996.

29 Róka E, A budai református templom - Szilágyi Dezső tér, Budapest, 1999.

30 Schulek János, Kísérletek új református templomstílus megteremtésére, Magyar református templomok (Kováts J I, ed.), Athenaeum, Budapest, 1942, pp. 339-349.

31 Sturm L Ch, Architectonisches Bedencken von Protestantischen Kleinen Kirchen Figur und Einrichtung, Augsburg, 1712.

$32 \ldots$, Vollständige Anweisung alle Arten von Kirchen Wohl Anzugeben, Augsburg, 1718.

33 Alžbeta Güntherová (ed.), Súpis Pamiatok na Slovensku, Vol. I-III, Slovenský Ústav Pamiatkovej Starostlivosti a Ochrany Prírody, Bratislava, 1967, 1968, 1969.

34 Szebik I, Várhegyi M, A miskolci evangélikus egyházközség története, Miskolc, 1983.

35 Winkler G, A soproni evangélikus templom helye Sopron épitészetében, Múvészet és felvilágosodás (Zádor A, Szabolcsi H, eds.), Akadémiai, Budapest, 1978, pp. 161-207.

36 _ Architectural History in Outline, Lutheran Churches in Hungary (Dercsényi B, ed.), Hegyi \& Company Publishing House, Budapest, 1992, pp. XXVII-XLV. 